39 Besinger RE, Niebyl JR, Keyes WG, Johnson TR. Randomised comparative trial of indomethacin and ritodrine for the long term treatm

40 Norton ME, Merrill J, Cooper BAB, Kuller JA, Clayman RI. Neonatal complications after the administration of indomethacin for preterm labor. $N$ Engl $f \mathrm{Med}$ 1993;329:1602-7.

41 Vemillion ST, Scardo JA, Lashus AG, Wiles HB. The effect of indomethacin tocolysis on fetal ductus arteriosus constriction with advancing gestational age. Am f Obstet Gynecol 1997; 177:256-9.

42 Carlan SJ, O'Brien WF, O'Leary TD, Mastrogiannis D. Randomised comparative trial of indomethacin and sulindac for the treatment of refractile preterm labour. Obstet Gynecol 1992;79:223-8.

43 Groom K, Sawdy R, Elliott C, Louden J, Shennan AH, Bennett PR. Experience of the use of nimesulide, a COX2 selective non steroidal anti inflammatory drug, in the prevention of preterm delivery in high risk cases. $\mathcal{F}$ Obstet vention of preterm delivery
Gynecol 2000;20(supp 1):61-2

44 Schrey MP, Read AM, Steer PJ. Oxytocin and vasopressin stimulate inositol phosphate production in human gestational myometrium and decidua cells. Biosci Rep 1986;6:613-19.

45 Magocsi M, Penniston JT. Oxytocin pretreatment of pregnancy rat uterus inhibits calcium uptake in plasma membrane and sarcoplasmic reticulum. Biochim Biophys Acta 1991;1063:7-14

46 Tasaka K, Masumoto N, Miyake A, Tanizawa O. Direct measurement of intracellular free calcium in cultured human puerperal myometrial cells stimulated by oxytocin effects of extracellular calcium and calcium channel blockers. Obstet Gynecol 1991;77:101-6.

47 Akerlund M, Stromberg P, Hauksson A, et al. Inhibition of uterine contractions of premature labour with an oxytocin analogue. Results from a pilot study. Br $\mathcal{F}$ Obstet Gynaecol 1987;94:1040-4.

48 Cole RM, Lamont RF. Current perspectives on drug treatment for preterm labour. $\mathcal{f}$ Obstet Gynaecol 1998;18:309-14.

49 Thomson AJ, Lunan CB, Cameron AD, Cameron IT, Greer IA, Norman JE. Nitric oxide donors induce ripening of the cervix: a randomised controlled trial. Br f Obstet Gynaecol

50 Higby K, Xenakis EMJ, Pauerstein CJ. Do tocolytic agents stop preterm labor? A critical and comprehensive review of efficacy and safety. Am F Obstet Gynecol 1993;168:1247-59.

51 Thornton S, Gillespie JI. Biochemistry of uterine contractions. Contemporary Reviews in Obstetrics and Gynaecology 1992;4:121-6.

52 Egarter CA, Husslein P. Biochemistry of myometrial contractility. Clin Obstet Gynecol 1992;6:755-69.

53 Caritis SN, Chiar JP, Kridgen P. Comparison of pulsatile and continuous ritodrine administration. effects on uterine contractility and beta adrenergic cascade. Am $\mathcal{f}$ Obstet Gynecol 1991;164:1005-12.

54 Hemminki E, Starfield B. Prevention and treatment of premature labour by drugs: review of controlled clinical trial. Br f Obstet Gynaecol 1978;85:411-17.
55 King JF, Grant A, Keirse MJNC, Chalmers I. Betamimetics in preterm labour: an overview of the randomised controlled trials. Br f Obstet Gynaecol 1988;95:211-22.

56 Canadian Preterm Labor Investigators Group. Treatment of preterm labor with the beta adrenergic agonist ritodrine. $N$ Engl F Med 1992;327:308-12.

57 Royal College of Obstetricians and Gynaecologists. RCOG guideline no 1(A): beta agonists for the care of women in preterm labour. London: Royal College of Obstetricians and Gynaecologists, Jan 1997.

58 Duty S, Weston AH. Potassium channel openers: pharmacological effects and future uses. Drugs 1990;40:785-91.

59 Weston $\mathrm{AH}$, Edwards G. Recent progress in potassium channel opener pharmacology. Biochem Pharmacol 1992;43:47-54.

60 Garfield RE, Sims SM, Daniel EE. Gap junctions: their presence and necessity in myometrium during parturition.

61 Rajabi M, Dean DD, Woessner Jr JF. High levels of serum collagenase in premature labor: a potential biochemical marker. Obstet Gynecol 1987;69:179-86.

62 Crowley P. Prophylactic corticosteroids for preterm delivery (Cochrane Review). In: The Cochrane library. Oxford: Update Software, 1999:issue 1.

63 Jobe A. Beneficial interactions of antenatal corticosteroids and postnatal surfactant. In: Report of the Consensus Development Conference on the Effect of corticosteroids for fetal opment Conference on the Effect of corticosteroids for fetal maturation on perinatal outcomes. Bethesda, MD: National Institutes of Child Health and Human Development. NIH
publication no 95-3784:39-41.

64 Crowther CA, Alfirevic Z, Haslam RR. Prophylactic prenatal thyrotrophin releasing hormone for preterm delivery (Cochrane Review). In: The Cochrane library. Oxford: Update Software, 1999:issue 1.

65 Alferevic Z, Boer K, Brocklehurst P, et al. Two trials of antenatal thyrotrophin-releasing hormone for fetal maturation: stopping before the due date. $\mathrm{Br} \mathcal{F}$ Obstet Gynaecol 1999:106:898-906.

66 Crowther CA, Henderson-Smart DJ. Prophylactic prenatal vitamin $\mathrm{K}$ for preterm birth (Cochrane Review). In: The Cochrane library. Oxford: Update Software, 1999:issue 1.

67 Crowther CA, Henderson-Smart DJ. Prophylactic prenatal phenobarbitol for preterm birth (Cochrane Review). In: The phenobarbitol for preterm birth (Cochrane Review). In: The

68 Thorp JA, Ferrette-Smith D, Gaston L, Johnson J, Yeast J, Myer B. Combined antenatal vitamin $\mathrm{K}$ and phenobarbitol therapy for preventing intracranial haemorrhage in newborns less than 34 weeks' gestation. Obstet Gynecol 1995;86:1-8.

69 King J, Flenady V. Antibiotics for preterm labour with intact membranes (Cochrane Review). In: The Cochrane library. Oxford: Update Software, 1999:issue 1.

70 Kenyon S, Boulvain M. Antibiotics for preterm premature rupture of membranes (Cochrane Review). In: The Cochrane library. Oxford: Update Software, 1999:issue 1.

71 Grant A. Elective versus selective Caesarean section for delivery of the small baby (Cochrane Review). In:The Cochrane library. Oxford: Update Software, 1999:issue 1.

\title{
STAMPS IN NEONATOLOGY
}

\section{Incubators}

Very seldom has an incubator been part of any stamp design. This Nepalese stamp was issued on 8th April 1988 to commemorate the Silver Jubilee of the Kanti Children's Hospital in Kathmandu. The stamp issuing details from the Postal Services Department describes the hospital as having 150 beds and the only children's hospital in the country catering "to the health needs of the children of the Kathmandu valley and other parts of the Kingdom as well". The stamp also bears the hospital logo. Four million stamps in sheets of 50 were printed by the Austrian Government Printing Office in Vienna.

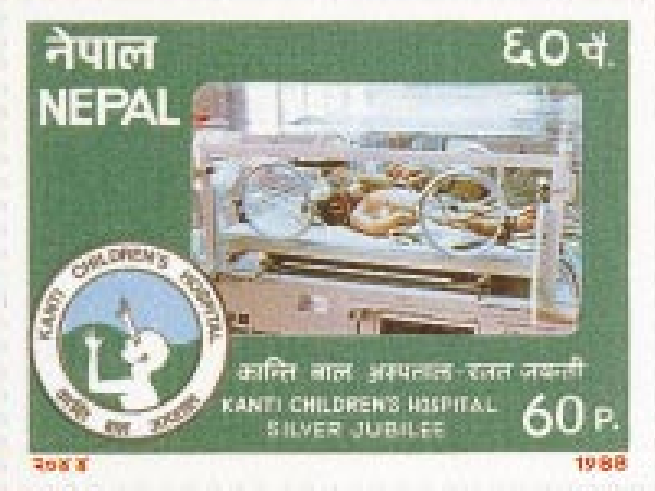

M K DAVIES

A J MAYNE 